Website: http://journal.umy.ac.id/index.php/mrs

DOI: $10.18196 / \mathrm{jmmr} .6129$

\title{
Kinerja Pusat Pertanggungjawaban Rumah Sakit dalam Perspektif Balanced Scorecard
}

\author{
Andi Nurcahya \& Suryo Pratolo* \\ * Penulis Korespondensi: spratolo@yahoo.com \\ * Program Studi Akuntansi Universitas Muhammadiyah Yogyakarta, Yogyakarta, Indonesia

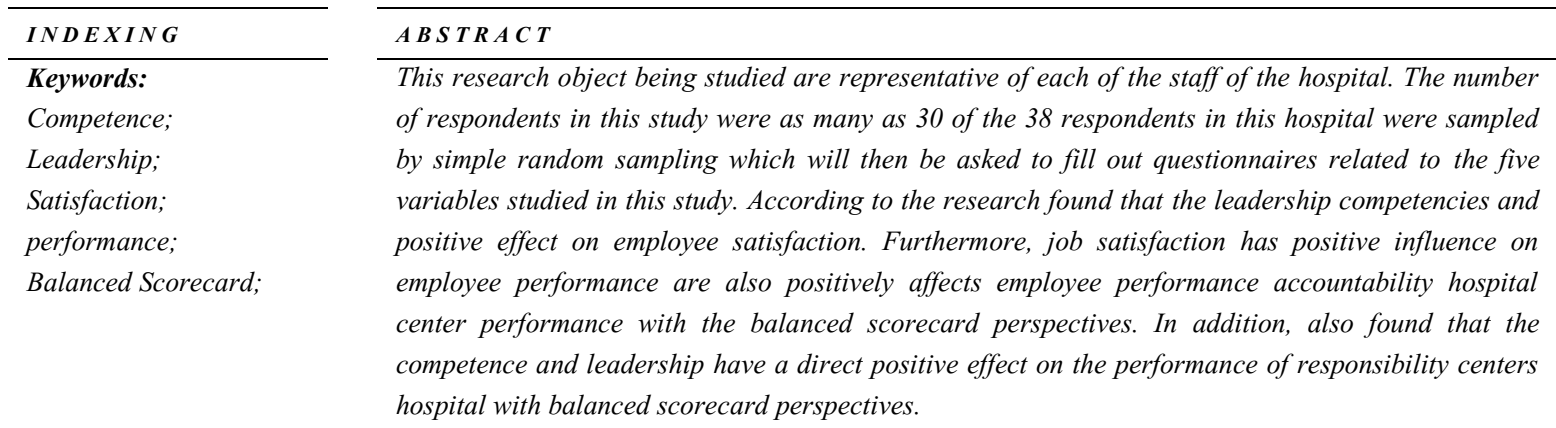

Kata kunci:

Kompetensi;

Kepemimpinan;

Kepuasan; Kinerja;

Balanced Scorecard;
Penelitian ini yang menjadi obyek penelitian adalah perwakilan dari masing-masing staf di RS tersebut. Jumlah responden dalam penelitian ini adalah sebanyak 30 dari 38 responden yang ada di Rumah Sakit tersebut yang diambil sampelnya dengan cara simple random sampling yang selanjutnya akan diminta mengisi angket kuesioner terkait kelima variabel yang diteliti dalam penelitian ini. Berdasarkan hasil penelitian ditemukan bahwa kompetensi dan kepemimpinan berpengaruh positif terhadap kepuasan kerja pegawai. Selanjutnya, kepuasan kerja berpengaruh positif terhadap kinerja pegawai yang pula kinerja pegawai berpengaruh positif terhadap kinerja pusat pertanggungjawaban rumah sakit dengan perspektif balanced scorecard. Selain itu, ditemukan pula bahwa kompetensi dan kepemimpinan memiliki pengaruh positif secara langsung terhadap kinerja pusat pertanggungjawaban rumah sakit dengan perspektif balanced scorecard.

(C) 2017 JMMR. All rights reserved

\section{PENDAHULUAN}

Ciri negara yang maju adalah kemajuan di bidang pelayanan kesehatan yang ditunjukkan dengan kinerja rumah sakit. Di Indonesia mengalami peningkatan jumlah pada Rumah Sakit Umum (RSU) dan Rumah Sakit Khusus (RSK) serta Tempat Tidurnya (TT). Pada tahun 2009 terdapat 1.202 RSU dengan kapasitas 141.603 TT, dan pada tahun 2013 meningkat menjadi 1.725 RSU dengan 245.340 TT. Pada tahun 2013, (53\%) RSU adalah milik swasta (profit dan non profit), disusul (30,4\%) RSU milik pemerintah Kabupaten/ Kota. RSK juga berkembang pesat, yakni dari 321 RSK dengan 22.877 TT pada tahun 2009 menjadi 503 RSK dengan 33.110 TT pada tahun 2013. RS Bersalin dan RS Anak terdapat pada RSK lebih dari separuh (51,3\%) Pada tahun 2013. Rumah sakit akan di prediksi pada tahun 2017 mengalami pertumbuhan hingga $2.368 \mathrm{RS}$, dengan laju pertumbuhan jumlah RS rata-rata 147 per tahun- 1 . Seharusnya dengan peningkatan jumlah rumah sakit setiap tahunnya dan bertambah pula kapasitas tempat tidur hingga di prediksi akan mencapai pertumbuhan pada tahun 2017 sebanyak 2.368 rumah sakit akan menambah pelayanan yang di berikan oleh kinerja rumah sakit.

Pada kenyataannya kinerja rumah sakit di Indonesia menunjukkan kondisi yang tidak sesuai dengan peningkatan jumlah rumah sakit dan bertambahnya kapasitas tempat tidur. Hal ini dapat di lihat dari sisi kesiapan pelayanan. Rifaskes 2011 menunjukkan data bahwa pencapaiannya belum memuaskan. Jumlah admisi pasien RS per 10.000 penduduk baru mencapai 1,9\%. Rata-rata Bed Occupancy Rate (BOR) RS baru 65\%. RS Kabupaten/ 
Kota yang mampu PONEK baru mencapai 25\% dan kesiapan pelayanan PONEK di RS pemerintah baru mencapai 86\%. Kemampuan Rumah Sakit dalam transfusi darah secara umum masih rendah (kesiapan rata-rata 55\%), terutama komponen kecukupan persediaan darah (41\% RS Pemerintah dan 13\% RS Swasta). Kementerian Kesehatan RI (2015). UndangUndang Republik Indonesia No 36 tahun 2014 tentang tenaga kesehatan menimbang bahwa tenaga kesehatan memiliki peranan penting untuk meningkatkan kualitas pelayanan kesehatan yang maksimal kepada masyarakat agar masyarakat mampu untuk meningkatkan kesadaran, kemauan, dan kemampuan hidup sehat sehingga akan terwujud derajat kesehatan yang setinggi-tinggginya sebagai investasi bagi pembangunan sumber daya manusia yang produktif secara sosial dan ekonomi serta salah satu unsur kesejahteraan umum sebagaimana dimaksud dalam pembukaan Undang-Undang Dasar Negara Indonesia Tahun 1945, dalam peraturan tersebut juga dijelaskan bahwa hak asasi manusia harus diwujudkan dengan salah satu caranya yaitu memberikan pelayanan kesahatan dan diberikan oleh tenaga kesehatan yang bertanggung jawab, yang memiliki etik dan moral yang tinggi, keahlian yang sudah terlatih. Permasalahan terletak pada kurang berkinerjanya rumah sakit dan atau pelayanan kesehatan di Indonesia, sehingga peneliti tertarik untuk menguji faktor-faktor yang bisa "menyembuhkan" kondisi tersebut.

Islam juga sudah lama mengatur tentang kerja dan menerangkan ayat tentang bekerja. Pekerjaan yang sudah kita kerjakan akan dilihat oleh banyak orang, sedangkan pekerjaan kita yang tidak terlihat akan diketahui oleh Allah SWT dan dimana pekerjaan yang melanggar aturan tersebut akan di pertanggung jawabkan kepada Allah. Islam menerangkan dan dimana ayat tersebut ter dapat dibawah ini:

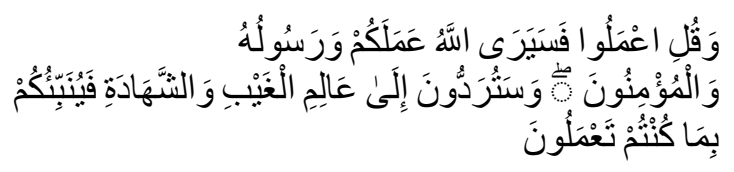

Al-Quran menjelaskan perintah bekerja yaitu dan katakanlah: "Bekerjalah kamu, maka Allah dan RasulNya serta orang-orang mukmin akan melihat pekerjaanmu itu, dan kamu akan dikembalikan kepada (Allah) Yang Mengetahui akan yang ghaib dan yang nyata, lalu diberitakanNya kepada kamu apa yang telah kamu kerjakan" (QS at-Taubah/9: 105). Islam mengenal pemisah antara dunia dan akhirat maka segala aktifitas merupakan amal yang diperintahkan menurut islam dan pekerjaan yang ia lakukan adalah semata-mata karena Allah SWT.

\section{METODE PENELITIAN}

Pada penelitian ini diuji keseluruhan variabel yang terdapat dalam penelitian terdahulu, yaitu pengaruh kompetensi, kepemimpinan, kepuasan dan kinerja karyawan terhadap kinerja pusat pertanggung jawaban dengan perspektif Balanced Scorecard. Model yang dipakai dalam penelitian ini dijelaskan pada gambar 1 .

Populasi yang digunakan adalah unit-unit yang ada didalam RSU PKU Muhammadiyah Gamping serta sampelnya adalah unit-unit tersebut. Pengambilan sampel menggunakan metode Simple Random Sampling dari 38 unit diambil 30 unit. Teknik pengumpulan data dilakukan dengan metode survey.

Data diperoleh dengan menggunakan kuesioner yang dibagikan ke responden secara acak di dalam setiap unit tersebut. Setiap unit mendapat 3 kuesioner dimana dari ketiga kuesioner tersebut akan di ambil rata-ratanya. Kuesioner Alhamdulillah kembali semua dari total 90 kuesioner yang saya sebarkan.

Metode analisis data menggunakan statistik deskriptif, analisis regresi linear berganda dan analisis jalur. Sebelum dilakukan analisis regresi, dilakukan uji pra syarat analisis regresi. Selanjutnya, analisis regresi dilakukan sebanyak 3 kali terkait diagram jalur yang akan dianalisis dalam penelitian ini. Analisis jalur merupakan perluasan dari analisis regresi linier berganda. Analisis jalur merupakan suatu teknik untuk menganalisis hubungan sebab akibat yang terjadi pada regresi linier berganda jika variabel eksogen memengaruhi variabel endogen tidak hanya secara langsung tetapi juga secara tidak langsung (Retherford dalam Ghozali $-3,-3$. Analisis jalur menggunakan diagram jalur untuk merepresentasikan permasalahan dalam bentuk gambar dan menentukan persamaan struktural yang menyatakan hubungan antar variabel pada diagram jalur tersebut $\stackrel{5}{\text {. }}$ 


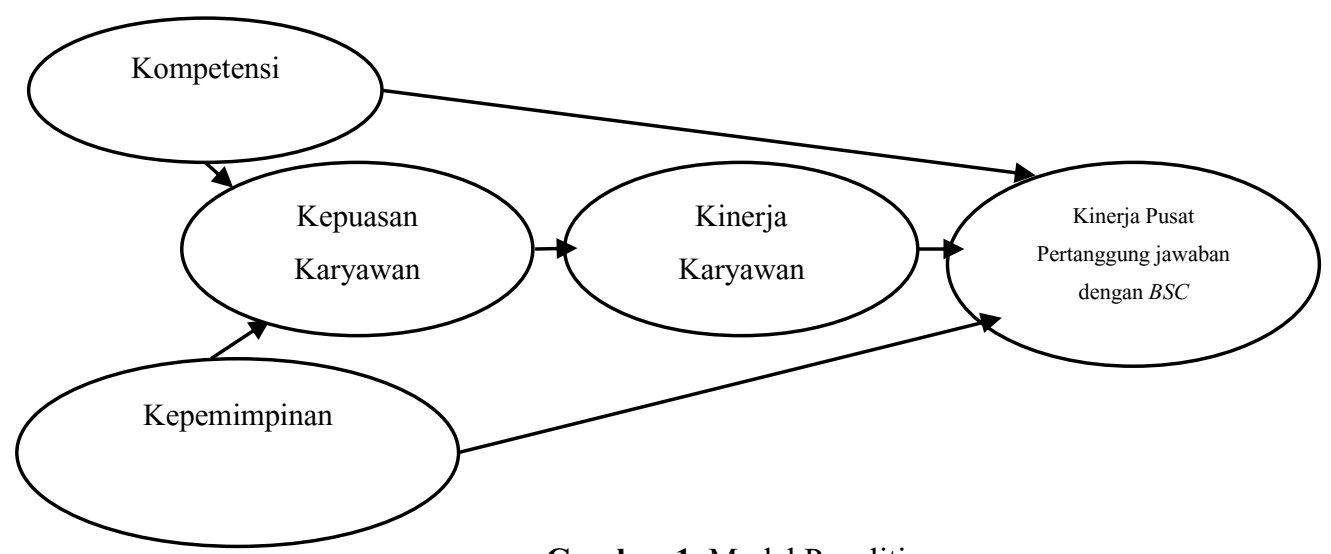

Gambar 1. Model Penelitian

Analisis jalur menggunakan diagram jalur untuk merepresentasikan permasalahan dalam bentuk gambar dan menentukan persamaan struktural yang menyatakan hubungan antar variabel pada diagram jalur tersebut. Diagram jalur dapat digunakan untuk menghitung pengaruh langsung dan tidak langsung dari variabel eksogen terhadap suatu variabel endogen. Pengaruh-pengaruh itu tercermin dalam apa yang disebut dengan koefisien jalur, dimana secara matematik analisis jalur mengikuti model struktural.

\section{HASIL DAN PEMBAHASAN}

Hasil uji validitas diketahui bahwa seluruh item pernyataan variable Kompetensi, Kepemimpinan, Kepuasan, Kinerja Pegawai, Kinerja Pusat Pertanggungjawaban dengan Perspektif Balanced Scorecard mempunyai nilai signifikan kurang dari 0,05 yang berarti seluruh item dalam kuesioner tersebut valid dalam mengukur variabel penelitian.

Menggunakan Balanced Scorecard untuk mengembangkan rumah sakit diharapkan finansial dan non finansial aspek dalam melakukan penilaian kinerja, sehingga nantinya diharapkan rumah sakit bisa menjadi institusi yang bisa memberikan kepuasan kepada kita pelanggan, karyawan yang memiliki komitmen tinggi dan kemudian akan menghasilkan surplus yang memadai $\stackrel{6}{-}$.

Uji reliabilitas yang digunakan dalam penelitian ini adalah uji reliabilitas dengan alpha crombach's. Suatu instrumen penelitian mengindikasikan reliabilitas yang memadai jika koefisien alpha crombach lebih besar atau sama dengan 0,70. Ketiga instrumen penelitian memiliki nilai crombach's alpha lebih dari
0,7 yang berarti ketiga instrumen penelitian reliabel (handal) dalam mengukur variabel penelitian?

Uji asumsi klasik tersebut meliputi uji normalitas, multikolinearitas, linearitas dan heteroskedastisitas. Uji normalitas dapat dilakukan dengan menggunakan uji normalitas Kolmogorv Sminov, berikut ini adalah hasil dari uji normalitas Kolmogorv Sminov dengan bantuan program SPSS. nilai signifikan hasil uji normalitas seluruh tahap regresi lebih besar dari 0,05 sehingga dapat disimpulkan bahwa residual dari Uji Multikolinearitas dilakukan untuk mengetahui ada tidaknya multikolinearitas antar variabel bebas dalam penelitian. Salah satu cara untuk melihat ada tidaknya multikolinearitas antar variabel bebas adalah dengan melihat nilai VIF dan tolerance yang didapat dari hasil analisis dengan bantuan program SPSS. Jika nilai VIF kurang dari 10 dan nilai Tolerance lebih dari 0,1 maka dikatakan tidak terdapat multikolinearitas antar variabel bebas dalam model regresi yang terbentuk, seluruh model penelitian berdistribusi normal atau dengan kata lain syarat normalitas terpenuhi oleh ketiga tahap regresi dan sebaliknya. didapat nilai VIF untuk semua variabel pada analisis regresi tahap 1 dan 2 kurang dari 10 dan nilai tolerance lebih dari 0,1 yang berarti tidak ada multikolinearitas antar variabel bebas dalam model regresi tahap 1 dan 2 , atau dengan kata lain syarat tidak adanya multikolinearitas terpenuhi.

Uji heteroskedastisitas dilakukan untuk mengetahui ada tidaknya heteroskedastisitas data penelitian, yaitu ketidaksamaan varian dan residual untuk semua pengamatan pada model regresi. Uji Heteroskedastisitas dapat dilakukan dengan analisis rank spearman. Seluruh variabel bebas pada analisis 
regersi tahap 1 dan 2 lebih dari 0,05 yang berarti tidak ada gejala heteroskedastisitas dalam data tersebut. Uji Linearitas digunakan untuk mengetahui bentuk hubungan dua variabel atau lebih dalam suatu model regresi. Dalam uji linear dengan bantuan SPSS, apabila nilai signifikan yang didapat lebih dari 0,05 maka hubungan kedua variabel dikatakan linear. nilai signifikan hasil uji linearitas variabel bebas seluruh tahap regresi kurang dari 0,05 yang berarti hubungan kedua variabel adalah linear.

Analisis regresi tahap 1 digunakan untuk mengetahui pengaruh variabel Kompetensi dan Kepemimpinan terhadap Kepuasan Kerja. koefisien Jalur variabel Kompetensi adalah 0,687 dengan nilai signifikan sebesar 0,000 dan koefisien jalur variabel Kepemimpinan adalah 0,339 dengan nilai signifikan sebesar 0,001, nilai signifikan kedua variabel $<0,05$ yang berarti koefisien jalur kedua variabel signifikan sehingga diperoleh diagram jalur sebagai berikut:

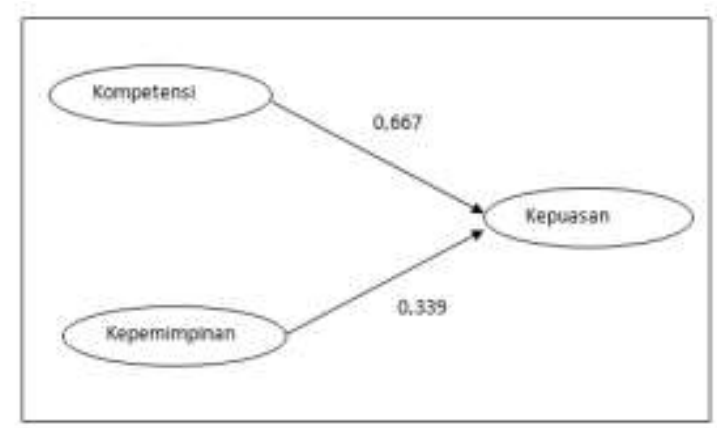

Gambar 2. Diagram Jalur Analisis Regresi Tahap I
Analisis regresi tahap 2 digunakan untuk mengetahui pengaruh variabel Kepuasan Kerja terhadap Kinerja Pegawai. Nilai Koefisien Jalur variabel Kepuasan terhadap Kinerja Pegawai adalah 0,896 sehingga diperoleh bentuk diagram jalur sebagai berikut:

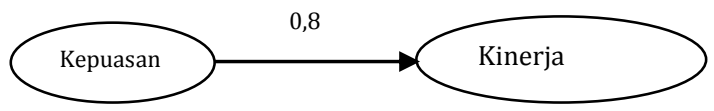

Gambar 3. Diagram Jalur Analisis Regresi Tahap II

Analisis regresi tahap 3 digunakan untuk mengetahui pengaruh variabel Kompetensi, Kepemimpinan dan Kinerja Pegawai terhadap Kinerja Pusat. Koefisien Jalur variabel Kompetensi adalah 0,335 dengan nilai signifikan sebesar 0,001, koefisien jalur variabel Kepemimpinan adalah 0,189 dengan nilai signifikan sebesar 0,018 dan Koefisien jalur variabel Kinerja Pegawai adalah 0,552 dengan nilai signifikan sebesar 0,000, nilai signifikan ketiga variabel $<0,05$ yang berarti koefisien jalur ketiga variabel signifikan sehingga diperoleh diagram jalur yang ditunjukkan pada Gambar 4.

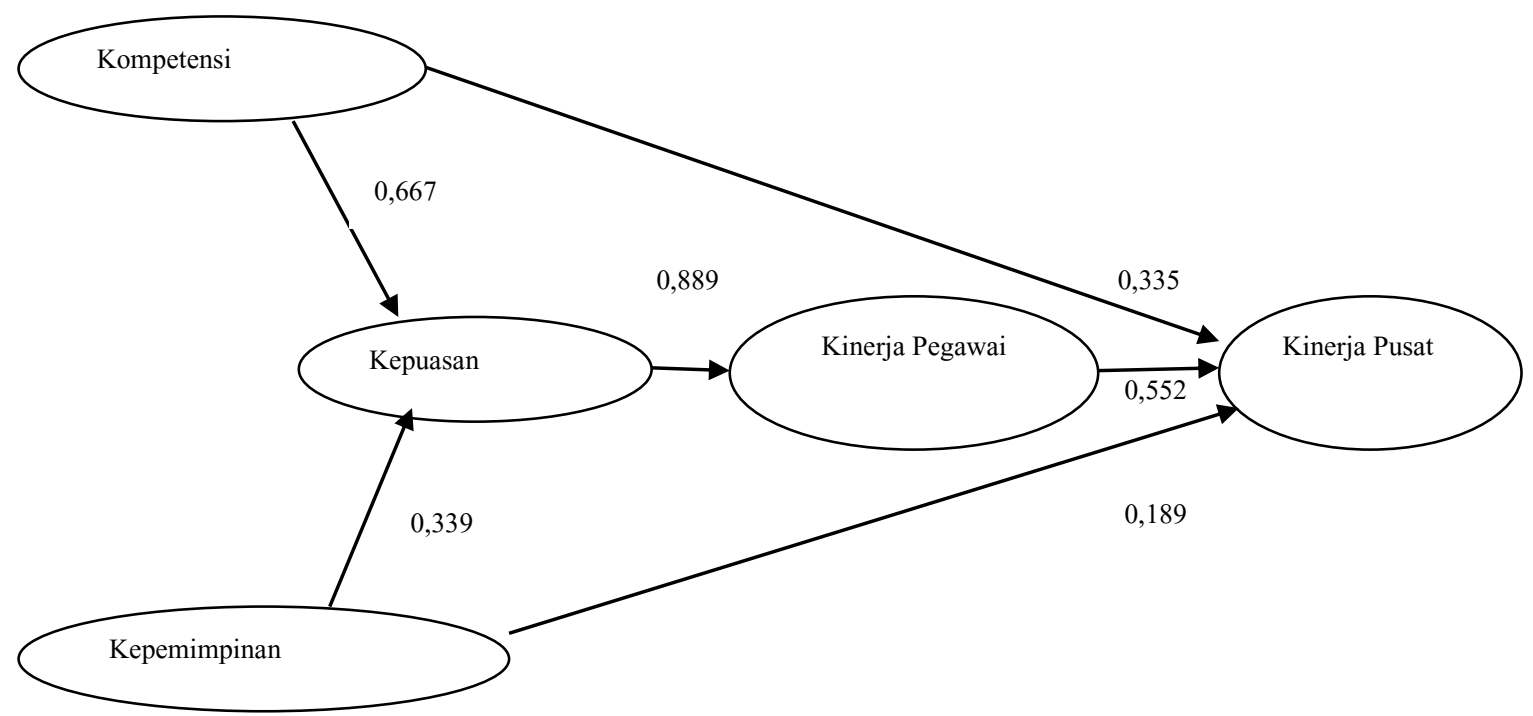

Gambar 4. Diagram Jalur Analisis Regresi Tahap III 
Kepemimpinan terhadap Kinerja Pusat $=0,339 \mathrm{x}$ $0,889 \times 0,552=0,166$. Pengaruh langsung $>$ Pengaruh tidak langsung yang berarti pengaruh Kepemimpinan terhadap Kinerja Pusat sebenarnya adalah langsung tanpa dimediasi oleh Kepuasan dan Kinerja Pegawai. Dari seluruh tahapan regresi di atas, didapat diagram jalur seperti berikut :

1) Berdasarkan hasil analisis regresi tahap I, nilai $t$ hitung variabel Kompetensi adalah 7,185 dan nilai signifikan sebesar $0,000<0,05$. Hal ini menunjukkan bahwa Kompetensi berpengaruh positif dan signifikan terhadap Kepuasan.

2) Berdasarkan hasil analisis regresi tahap $I$, nilai $t$ hitung variabel Kepemimpinan adalah 3,548 dan nilai signifikan sebesar $0,001<0,05$. Hal ini menunjukkan bahwa Kepemimpinan berpengaruh positif dan signifikan terhadap Kepuasan Karyawan.

3) Berdasarkan hasil analisis regresi tahap II, nilai $t$ hitung variabel Kompetensi adalah 10,649 dan nilai signifikan sebesar $0,000<0,05$. Hal ini menunjukkan bahwa Kepuasan berpengaruh positif dan signifikan terhadap Kinerja Pegawai.

4) Berdasarkan hasil analisis regresi tahap III, nilai $t$ hitung variabel Kompetensi adalah 5,667 dan nilai signifikan sebesar $0,000<0,05$. Hal ini menunjukkan bahwa Kinerja Karyawan berpengaruh positif dan signifikan terhadap Kinerja Pusat.

5) Berdasarkan hasil analisis regresi tahap III, nilai t hitung variabel Kompetensi adalah 3,630 dan nilai signifikan sebesar $0,001<0,05$. Hal ini menunjukkan bahwa Kompetensi berpengaruh positif dan signifikan terhadap Kepuasan.

6) Berdasarkan hasil analisis regresi tahap III, nilai $t$ hitung variabel Kompetensi adalah 2,515 dan nilai signifikan sebesar $0,018<0,05$. Hal ini menunjukkan bahwa Kepemimpinan berpengaruh positif dan signifikan terhadap Kepuasan.

\section{SIMPULAN}

Berdasarkan hasil penelitian didapat beberapa kesimpulan yakni, kompetensi berpengaruh positif dan signifikan terhadap Kepuasan. Semakin tinggi kompetensi yang dimiliki pegawai semakin tinggi pula
Kepuasan Kerja yang diperolehnya, begitu sebaliknya. Kepemimpinan berpengaruh positif dan signifikan terhadap Kepuasan. Semakin tinggi kualitas kepemimpinan rumah sakit semakin tinggi pula Kepuasan Kerja yang diperoleh pegawainya, begitu sebaliknya. Kepuasan berpengaruh positif dan signifikan terhadap Kinerja Pegawai. Semakin tinggi Kepuasan Pegawai maka semakin tinggi pula Kinerja Pegawai, begitu sebaliknya. Kinerja Pegawai berpengaruh positif dan signifikan terhadap Kinerja pusat pertanggungjawaban Rumah Sakit dalam perspektif Balanced Scorecard. Semakin tinggi kinerja pegawai maka semakin tinggi pula kinerja pusat pertanggungjawaban Rumah Sakit dalam perspektif Balanced Scorecard, begitu sebaliknya.

Kompetensi berpengaruh positif dan signifikan terhadap Kinerja pusat pertanggungjawaban Rumah Sakit dalam perspektif Balanced Scorecard. Semakin tinggi kompetensi yang dimiliki pegawai aka semakin tinggi pula kinerja pusat pertanggungjawaban Rumah Sakit dalam perspektif Balanced Scorecard, begitu sebaliknya. Kepemimpinan berpengaruh positif dan signifikan terhadap Kinerja pusat pertanggungjawaban Rumah Sakit dalam perspektif Balanced Scorecard. Semakin tinggi kualitas kepemimpinan maka semakin tinggi pula kinerja pusat pertanggungjawaban Rumah Sakit dalam perspektif Balanced Scorecard, begitu sebaliknya.

\section{DAFTAR PUSTAKA}

1. Kementerian Kesehatan RI. 2015, "Rencana Strategis Kementerian Kesehatan Tahun 2015-2019”. http://www.depkes.go.id/resources/download/infopublik/Renstra-2015.pdf, 15 Maret 2016 (1)

2. Ghozali, Imam, (2008), Model Persamaan Struktural Konsep dan Aplikasi dengan Program Amos 16.0, Badan Penerbit UNDIP, Semarang. (2)

3. Ghozali, Imam, 2009. Aplikasi Analisis Multivariate Dengan Program SPSS, Edisi Keempat, Penerbit Universitas Diponegoro. (3)

4. Ghozali, Imam. 2011. "Aplikasi Analisis Multivariate Dengan Program SPSS”. Semarang: Badan Penerbit Universitas Diponegoro (4)

5. Sekaran, Uma, 2006. Metodologi Penelitian Untuk Bisnis, Jakarta: Salemba Empat. (5)

6. Aurora, Novella. Mei 2010, " Penerapan Balanced Scorecard sebagai Tolak Ukur Pengukuran Kinerja”. 
Skripsi Universitas DIponegoro, http://eprints.undip.ac.id/22583/, 22 Maret 2016

7. Amin, Namira Mardi. Juni 2015, "Pengaruh Kompetensi terhadap Kinerja Pegawai di Sekretariat Daerah Kabupaten Sindenreng Rappang”. Skripsi Universitas Hasanuddin Fakultas Ilmu Sosial dan Ilmu Politik. 